\title{
Diagnostic peritoneal lavage in hemodynamically stable patients with lower chest or anterior abdominal stab wounds
}

\author{
Hemodinamik açıdan stabil, gögüs altı veya ön karın bölgesinde \\ bıçak yaralanması olan hastalarda tanısal peritoneal lavaj
}

\author{
Shahriar HASHEMZADEH, Kamran MAMEGHANI, Rohollah F FOULADI, EInaz ANSARI
}

\section{BACKGROUND}

Managing hemodynamically stable patients with thoracoabdominal stab wounds is still under dispute. This study aimed at discussing cut-off points of red blood cell (RBC) count in diagnostic peritoneal lavage (DPL) effluent in these patients.

\section{METHODS}

Three hundred and eighty-eight patients with thoracoabdominal stab wounds and hemodynamically stable status were enrolled. In cases without a clear indication of laparotomy, the peritoneal cavity was washed out with $1000 \mathrm{ml}$ of normal saline and the effluent fluid was analyzed for RBC count. RBC counts of $>100,000 / \mathrm{mm}^{3}$ in abdominal wounds and of $>10,000 / \mathrm{mm}^{3}$ in lower chest wounds were considered as indications for exploratory laparotomy (conventional approach). New cut-off points for RBC count were calculated in backward analysis.

\section{RESULTS}

Sensitivity and specificity of the conventional approach were $90 \%$ and $84 \%$, respectively. RBC counts $>15,000 /$ $\mathrm{mm}^{3}$ in abdominal wounds and $>25,000 / \mathrm{mm}^{3}$ in lower chest wounds were the best cut-off points in distinguishing patients with and without need of operation, with a sensitivity and specificity of $94 \%$ and $96 \%$, respectively.

\section{CONCLUSION}

New cut-off points of RBC count in DPL effluent may promote management of patients with thoracoabdominal stab wounds and no obvious indication for operation.

Key Words: Thoracoabdominal stab wounds; laparotomy; thoracotomy; diagnostic peritoneal lavage; red blood cell.

\begin{abstract}
$\boldsymbol{A M A C}$
Torakoabdominal bıçak yaralanmaları bulunan ve hemodinamik açıdan stabil olan hastaların tedavisi halen tartışmalıdır. Bu çalışmada, bu tip hastalardaki tanısal peritoneal lavaj (TPL) sıvısındaki eritrosit sayısındaki optimal değer tartışıldı.
\end{abstract}

\section{GEREÇ VE YÖNTEM}

Hemodinamik yönden stabil ve torakoabdominal bıçak yaralanması olan 388 hasta çalışmaya alındı. Laparotomi yönünden açık bir endikasyona sahip olmayan olgularda, peritoneal kavite 1000 cc serum fizyolojikle yıkandı ve akıntı sıvısındaki eritrosit sayısı analiz edildi. Karın yaralarında $>100,000 / \mathrm{mm}^{3}$ ve alt göğ̈̈s yaralarında $>10,000 / \mathrm{mm}^{3}$ seviyesinde eritrosit sayısı eksploratuvar laparotomi (konvansiyonel yaklaşım) için endikasyonlar olarak kabul edildi. Geriye dönük yapılan analizde, eritrosit sayısı için yeni eşik değerler hesaplandi.

\section{BULGULAR}

Konvansiyonel yaklaşımın duyarlılığı ve özgüllüğü, sırasıyla \%90 ve \%84 olmuştur. Karın yaralarında $>15,000 /$ $\mathrm{mm}^{3}$ ve alt göğüs yaralarında $>25,000 / \mathrm{mm}^{3}$ seviyesindeki eritrosit sayıs1, operasyon gereksinimi olan veya olmayan hastaların ayırt edilmesinde, sırasıyla \%94 ve \%96'lık bir duyarlılık ve özgüllük ile en uygun eşik değeri bulundu.

\section{SONUÇ}

Tanısal peritoneal lavaj sıvısında eritrosit sayısı ile ilgili yeni eşik değer, torakoabdominal bıçak yaralanmaları bulunan ve hiçbir açık operasyon endikasyonu bulunmayan TPL hastalarının tedavisine kullanılabilir.

Anahtar Sözcükler: Torakoabdominal bıçak yaralanmaları; laparotomi; torakotomi; tanısal peritoneal lavaj; eritrosit. 
Prior to the 20th century, high mortality rates were the rule when stab or gunshot wounds were managed non-operatively. ${ }^{[1]}$ Dealing with penetrating abdominal stab wounds has remained under debate. Traditionally, concern of delayed diagnosis of intra-abdominal injuries has led many trauma centers to propose mandatory abdominal exploration when a penetrating stab wound into the abdominal cavity was suspected. ${ }^{[2,3]}$ Selective operative management of asymptomatic patients was therefore advocated in 1960, when it was revealed that $25 \%$ to $33 \%$ of patients with stab wounds had no peritoneal penetration, and in penetrated cases, significant injuries were present in only some $45 \%$. ${ }^{[4,5]}$ This liberal approach resulted in a reluctant acceptance of a $50 \%$ incidence of non-therapeutic laparotomies in an attempt to prevent delayed diagnosis of intra-abdominal injuries. ${ }^{[6]}$ In order to overcome the diagnostic delay and concomitantly reduce the number of non-therapeutic laparotomies, diagnostic peritoneal lavage (DPL) was employed, which resulted in a reduced incidence of non-therapeutic laparotomies to $7 \%-15 \% \cdot{ }^{[7]}$ Since the initial description of DPL in 1965 , and emergence of the promoted type in 1977 , this test has been considered as a tool to triage patients in the emergency ward to the operating room. ${ }^{[8,9]}$ This is despite the availability of more sophisticated and less invasive options in managing patients with thoracoabdominal trauma, such as computed tomography (CT), focused assessment with sonography for trauma (FAST), thoracoscopy, or laparoscopy. However, DPL has remained a cornerstone in trauma work-up because the mentioned techniques are expensive and time-consuming, with variable diagnostic sensitivity/ specificity, especially in penetrating thoracoabdominal trauma. ${ }^{[10-14]}$ Using the DPL, one ideally wants to avoid missed injuries and minimize unnecessary operations. The red blood cell (RBC) count in DPL effluent fluid has been proposed as a sensitive and specific indicator; however, the optimal cut-off point is still controversial. In our center, at least, as a main referral place for such victims, the current guidelines are apparently unsatisfying.

This study aimed at re-evaluating current cut-off points of the RBC count in DPL effluent fluid in patients with lower chest or anterior abdominal stab wounds.

\section{MATERIALS AND METHODS}

In a prospective setting, hemodynamically stable patients with stab wound injuries to the anterior abdomen or lower chest were evaluated during a four-year period (2007-2011) at an urban level I trauma center in Tabriz, Iran. The anterior abdomen was defined as a region confined to the inferior costal margin superiorly, the inguinal ligament inferiorly, and the anterior axillary lines laterally. ${ }^{[15]}$ The lower chest (or thorax) was defined as a region placed between the anterior abdomen inferiorly and the forth intercostal space superiorly. ${ }^{[16]}$ The managing protocol is summarized in Figure 1.

Hemodynamically unstable patients (systolic blood pressure $<90$ ) and/or patients in need of urgent opera-

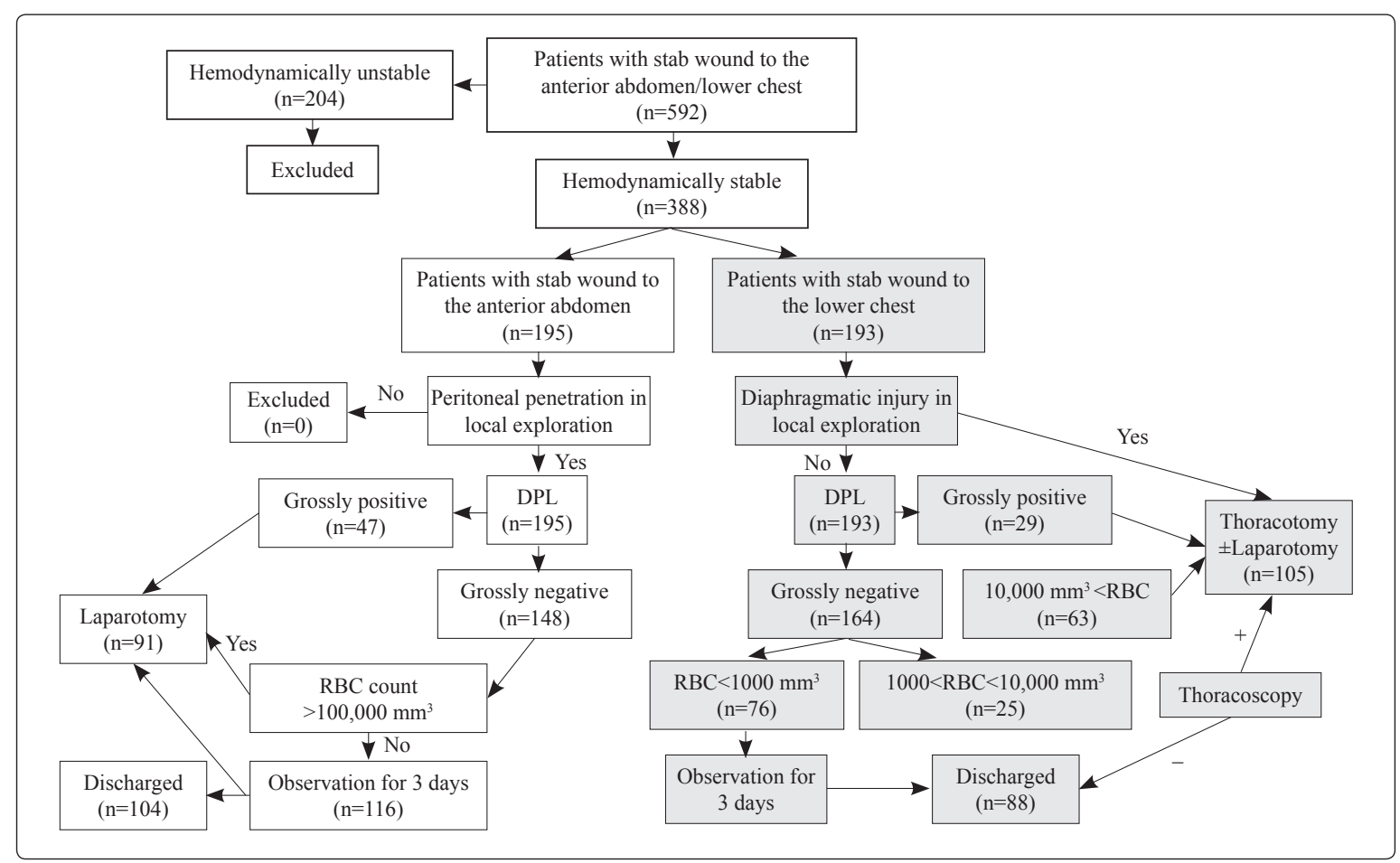

Fig. 1. The flow chart of management in patients with thoracoabdominal stab wounds. 
tion for any reason (evisceration, peritonitis, etc.) were excluded. The peritoneum or diaphragmatic violation was confirmed by exploration under local anesthesia. Open DPL was performed through a lunar incision on the left side of the umbilicus. The DPL was considered grossly positive when more than $10 \mathrm{ml}$ of free blood was aspirated through the catheter. In lesser volumes, $1 \mathrm{~L}$ of saline was instilled and the patient was gently rocked in different directions. In the aspirated effluent, RBC counts $>100,000 / \mathrm{mm}^{3}$ and $>10,000 / \mathrm{mm}^{3}$ were considered positive in anterior abdominal and lower thoracic lesions, respectively. In the latter, thoracoscopy was performed when the RBC count was between 1,000 and $10,000 / \mathrm{mm}^{3}$. Presence of bile, vegetable or fecal material, or observation of effluent draining through a chest tube, nasogastric tube, or Foley catheter was also considered as a grossly positive result. ${ }^{[17]}$ Exploratory laparotomy or thoracoscopy was performed in cases with a grossly positive finding or a positive DPL result. Otherwise, the patients were meticulously monitored for at least three days. ${ }^{[18,19]}$ Development of hemodynamic instability, peritonitis, or evidence of ongoing blood loss prompted laparotomy. Otherwise, the patient was discharged after feeding was tolerated. All the stable patients with easily and immediate access to our center were advised to present for another visit 10 days after discharge. These patients and their family members were informed about possible alerting signs or symptoms during their stay at home. Working backward, the RBC count in DPL effluent was employed for calculating an optimal cutoff point based on the final diagnosis made according to results of laparotomy, thoracoscopy or 10-day follow-up. The sensitivity was defined as the ability of the DPL to detect an injury (or penetration) to the visceral and/or intra-abdominal organs or the diaphragm, if present, and the specificity was defined as the ability of the DPL to rule out an injury (or penetration) to the visceral and/or intra-abdominal organs or the diaphragm if none existed. ${ }^{[8]}$

This study was approved by the Ethics Committee of our University of Medical Sciences. Data were analyzed with the SPSS statistical software package (version 15.0; SPSS Inc, Chicago). Receiver operating characteristic (ROC) curve coordinates were used for determining optimal cut-off points of the RBC count in DPL effluent fluid. Continuous variables were expressed as mean \pm standard deviation, and categorical data were shown as frequency and percent. The contingency table (chi-square and Fisher's exact tests where appropriate) was employed for comparisons. A p value less than 0.05 was considered statistically significant.

\section{RESULTS}

Five hundred ninety-two patients with lower chest or anterior abdominal stab wound injuries were re- ferred to our center during the study period. Three hundred and eighty-eight patients met the criteria and were enrolled in the study. There were 195 patients $(50.3 \%)$ with isolated anterior abdominal stab wounds (Group A) and 193 patients (49.7\%) with isolated injuries in the lower chest (Group B). In Group A, there were 181 males $(92.8 \%)$ and 14 females $(7.2 \%)$, with a mean age of $23.3 \pm 7.3(15-52)$ years. In Group B, there were 184 males $(95.3 \%)$ and 9 females $(4.7 \%)$, with a mean age of $27.2 \pm 9.0$ (19-48) years. Initial aspiration and subsequent DPL analysis yielded a grossly positive result in 76 patients (19.6\%), including 47 cases in Group A and 29 cases in Group B. A therapeutic laparotomy was performed in all these patients. The RBC in DPL was counted in the remaining 312 patients $(80.4 \%$ including 148 cases in Group A and 164 cases in Group B). After RBC count, 76 patients (24.4\%) underwent exploratory laparotomies including 32 cases in Group A and 44 cases in Group B.

Thirty-two patients with lower chest wounds were evaluated by thoracoscopy, all with negative findings, and the remaining 204 patients $(75.6 \%)$ were closely observed, including 116 cases in Group A and 88 cases in Group B. In the three-day observational period, 12 other patients in Group A underwent operation due to emergence of an indication. Finally, 192 patients were discharged without any intervention including no laparotomy or thoracoscopy. There were no deaths and/or major complications 10 days after discharge. Intra-operative findings were present in 83 cases in Group A, including injury to the small bowel (41 patients), colon (16 patients), liver (8 patients), vessels (8 patients), stomach (7 patients), spleen ( 2 patients) and gallbladder (1 patient). In Group B, similar findings were present in 37 cases, including injury to the diaphragm (23 patients), lung ( 9 patients), stomach (4 patients), and spleen (1 patient). The final outcomes after management of the patients are summarized in Table 1 .

By backward analysis of the patients, $\mathrm{RBC}$ counts $>15,000 / \mathrm{mm}^{3}$ in Group A and $>25,000 / \mathrm{mm}^{3}$ in Group $\mathrm{B}$ were the optimal cut-off points in distinguishing patients with or without need of further evaluation (Table 2).

By applying the new cut-off points, specificities were significantly improved in patients with lower chest stab wounds and overall (odds ratio $=0.8,95 \%$ confidence interval $0.7-0.9, \mathrm{p}<0.001$, and odds ratio $=4.6,95 \%$ confidence interval $1.5-14.2, p=0.005$, respectively).

\section{DISCUSSION}

Diagnostic peritoneal lavage (DPL) has been introduced as one of the sensitive procedures in the management of patients with penetrating injuries to their 
Table 1. Outcome of the conventional management* in patients with stab wound injuries to the anterior abdomen or the lower chest

\begin{tabular}{|c|c|c|c|c|c|c|c|c|}
\hline Location & A & B & $\mathrm{C}$ & $\mathrm{D}$ & $\mathrm{E}$ & $\mathrm{F}$ & G & $\mathrm{H}$ \\
\hline Lower chest & $37(19.2 \%)$ & $120(62.2 \%)$ & $36(18.6 \%)$ & - & $100 \%$ & - & $77 \%$ & $0.7-0.8$ \\
\hline Anterior abdomen & $71(36.4 \%)$ & $104(53.3 \%)$ & $8(4.1 \%)$ & $12(6.2 \%)$ & $86 \%$ & $0.7-0.9$ & $93 \%$ & $0.9-1.0$ \\
\hline Overall & $108(27.8 \%)$ & $224(57.7 \%)$ & $44(11.3 \%)$ & $12(3.2 \%)$ & $90 \%$ & $0.8-1.0$ & $84 \%$ & $0.8-0.9$ \\
\hline
\end{tabular}

A: True positive; B: True negative; C: False positive; D: False negative; E: Sensitivity; F: 95\% confidence interval; G: Specificity; H: 95\% confidence interval.

* Red blood cell count $>100,000 / \mathrm{mm}^{3}$ and $>10,000 / \mathrm{mm}^{3}$ in anterior abdominal and lower thoracic lesions, respectively.

Table 2. Outcome of the new management* in patients with stab wound injuries to the anterior abdomen or the lower chest

\begin{tabular}{|c|c|c|c|c|c|c|c|c|}
\hline Location & A & B & $\mathrm{C}$ & $\mathrm{D}$ & $\mathrm{E}$ & $\mathrm{F}$ & G & $\mathrm{H}$ \\
\hline Lower chest & $37(19.2 \%)$ & $156(80.8 \%)$ & - & - & $100 \%$ & - & $100 \%$ & - \\
\hline Anterior abdomen & $76(39 \%)$ & $100(51.2 \%)$ & $12(6.2 \%)$ & $7(3.6 \%)$ & $92 \%$ & $0.8-0.0$ & $89 \%$ & $0.8-0.9$ \\
\hline Overall & $113(29.1 \%)$ & $256(66 \%)$ & $12(3.1 \%)$ & $7(1.8 \%)$ & $94 \%$ & $0.9-1.0$ & $96 \%$ & $0.9-1.0$ \\
\hline
\end{tabular}

A: True positive; B: True negative; C: False positive; D: False negative; E: Sensitivity; F: 95\% confidence interval; G: Specificity; H: $95 \%$ confidence interval.

* Red blood cell count $>15,000 / \mathrm{mm}^{3}$ and $>25,000 / \mathrm{mm}^{3}$ in anterior abdominal and lower thoracic lesions, respectively.

lower chest or anterior abdomen. However, appropriate approaches and indices are still under debate. In this study, we showed that aspiration of a grossly positive fluid, i.e. gross blood volume $>10 \mathrm{ml}$ and/or traces of feces, food remnants and bile, would lead to unexceptionally therapeutic laparotomies. Nagy et al., ${ }^{[20]}$ in contrast, concluded that because aspiration-positive patients are not more critically injured or unstable than DPL-positive patients, and because DPL is more accurate in detecting need of operative intervention, aspiration should be withheld as a part of the DPL procedure in patients with abdominal trauma. In another series, Drost et al. ${ }^{[21]}$ showed that a grossly positive peritoneal lavage might lead to "false- positive" results in patients with penetrating abdominal wounds. They indicated that such "false- positive" lavages most commonly result from blood entering the abdominal cavity from the wound, although nonoperative injuries to solid viscera and iatrogenic trauma are sometimes implicated. Considering "quantity" and "quality" in evaluating the initial aspiration of the peritoneal cavity in patients thusly injured seems to be the main difference between the current study and others. Aspiration not as a separate procedure but as an initial part of a DPL can be quickly evaluated without wasting time. The rather large number of patients (76 cases) in our study with $100 \%$ therapeutic consequent laparotomies was a great advantage in present study. Sriussadaporn et al. ${ }^{[22]}$ also found that during use of DPL in patients with stab wounds in the anterior abdomen, initial aspiration of gross blood from the lavage catheter of more than $10 \mathrm{ml}$ is a highly sensitive indicator of injury. Apparently, inward bleeding of a stab wound will hardly reach a volume of $10 \mathrm{ml}$, and this amount of gross blood probably originates from an organ laceration. The RBC count in a negative DPL effluent fluid, indi- cating an injury of visceral and/or intra-abdominal organ in patients with lower chest or anterior abdominal stab wounds, is one of the most controversial indices. By now, various studies have recommended different cut-off points for RBC count in patients with thoracoabdominal stab wounds. In Thacker's study ${ }^{[23]}$ in patients with stab wounds to the anterior lower chest and/or abdomen, a RBC count $>100,000 \mathrm{~mm}^{3}$ in DPL effluent fluid was reported to be an accurate cut-off point, particularly when it was employed along with other positive criteria such as increased white cells, bile and amylase. In another study by Henneman ${ }^{[24]}$ in 336 patients with penetrating trauma, the initial DPL according to the conventional guideline yielded a sensitivity of $87 \%$ and a specificity of $89 \%$ in predicting the need of operation. Sriussadaporn et al. ${ }^{[22]}$ reported that a RBC count in lavage fluid $>10,000 / \mathrm{mm}^{3}$ as a positive criterion for exploratory laparotomy yielded a sensitivity and a specificity of $100 \%$ and $87 \%$, respectively. Zappa et al. ${ }^{[25]}$ concluded that a RBC count of $50,000 / \mathrm{mm}^{3}$ discriminated satisfactorily those patients who required surgery from those who did not. Flaws in the management of patients and a variety of other disadvantages limit the accuracy of these studies. ${ }^{[26-29]}$

In our series, the intra-operative findings were present in 83 cases in Group A, including 8 liver and 2 spleen injuries. In Group B, similar findings were present in 37 cases, including 23 cases with diaphragm, 9 patients with lung and 1 patient with spleen injuries. All these cases underwent therapeutic laparotomy/thoracotomy based on the criteria employed, such as a grossly positive DPL or increased RBC count, thoracoscopic findings or emergence of alerting signs/symptoms within the observational period (Fig. $1)$. None of them could be treated by nonoperative management. 
Excluding the patients with grossly positive results, we reported new optimal cut-off points for RBC count in DPL effluent fluid with more accurate outcomes. A RBC count in DPL effluent fluid of $>25,000 / \mathrm{mm}^{3}$ in lower chest wounds and of $>15,000 / \mathrm{mm}^{3}$ in the anterior abdomen led to a sensitivity of $94 \%$ and a specificity of $96 \%$, which were greatly better than the results of the conventional approach, including a RBC count $>10,000 / \mathrm{mm}^{3}$ in lower chest injuries and of $>100,000 /$ $\mathrm{mm}^{3}$ in the anterior abdomen, with a sensitivity of $90 \%$ and a specificity of $84 \%$. To our knowledge, these results are the best ever reported in this group of patients in the literature. It should be noted that all the new cut-offs of RBC counts in the present study were made in a backward fashion; i.e., the outcome was clear and the new cut-offs were not tested in a fresh group of patients. Indeed, the main objective of this study was to evaluate and propose, if possible, new cut-offs of $\mathrm{RBC}$ counts in this group. It could be claimed that the new figures could omit or decrease the rate of delayed diagnosis of real injured cases after the phase of employment of previously proposed cut-offs; i.e. after more invasive evaluations such as thoracoscopy or exploratory laparotomy, or during the close observational periods. Of course, the new proposed cut-offs will cut the rate of false-negative or false-positive cases encountered in this study, and the high diagnostic accuracy confirms this; however, their efficiency in decreasing unnecessary and nontherapeutic operations while at the same time preventing missed cases needs to be examined in future patients in further studies using the same protocol along with the newly proposed RBC count cut-offs in DPL.

There are a few of limitations to this study. Although this study was performed in a prospective manner, further randomized investigations might be ideal to prove the concept. A five-year period with a certain number of changing surgeons might be another issue. Conducting similar studies in other centers may further elucidate the findings. The close follow-up period was 10 days in the current study, which may seem short. During this follow-up period, repeated contact is made by the medical staff with the patients or the relatives responsible for their care. The contact persons are fully educated about the condition and alerting signs/symptoms before discharge. In addition, only the patients with easy and rapid access to the medical centers were allowed to stay at home after three days of in-hospital observation. Working in a major referral center and with a considerable amount of experience, the authors believe that this period is sufficient to closely follow patients with thoracoabdominal penetrating injuries. The upcoming results also confirmed this concept. Nonetheless, as mentioned earlier, we only recruited patients who were in close contact for immediate action, and regular visits were performed after this period of time, but not as closely as in the mentioned 10-day period.

In conclusion, the results of DPL assessment in stable patients with stab wounds in the lower chest or anterior abdomen could be considered as an accurate and safe method of management. Apparently, this is more complex in anterior abdominal stab wounds compared with injuries in the lower chest. However, combining DPL findings based on the newly proposed cut-off points with a rather short period of observation in patients with negative results might increase the sensitivity and specificity of management. Further studies with larger sample sizes, particularly in patients with anterior abdominal injuries, are recommended. Penetrating lesions in the back and flank are important issues as well.

\section{REFERENCES}

1. van Haarst EP, van Bezooijen BP, Coene PP, Luitse JS. The efficacy of serial physical examination in penetrating abdominal trauma. Injury 1999;30:599-604. CrossRef

2. Buck GC 3rd, Dalton ML, Neely WA. Diagnostic laparotomy for abdominal trauma. A university hospital experience. Am Surg 1986;52:41-3.

3. Ivatury RR, Simon RJ, Stahl WM. A critical evaluation of laparoscopy in penetrating abdominal trauma. J Trauma 1993;34:822-8. CrossRef

4. Feliciano DV, Bitondo CG, Steed G, Mattox KL, Burch JM, Jordan GL Jr. Five hundred open taps or lavages in patients with abdominal stab wounds. Am J Surg 1984;148:772-7.

5. Moore EE, Marx JA. Penetrating abdominal wounds. Rationale for exploratory laparotomy. JAMA 1985;253:2705-8.

6. Nance FC, Wennar MH, Johnson LW, Ingram JC Jr, Cohn I Jr. Surgical judgment in the management of penetrating wounds of the abdomen: experience with 2212 patients. Ann Surg 1974;179:639-46. CrossRef

7. Feliciano DV. Diagnostic modalities in abdominal trauma. Peritoneal lavage, ultrasonography, computed tomography scanning, and arteriography. Surg Clin North Am 1991;71:241-56.

8. Root HD, Hauser CW, McKinley CR, Lafave JW, Mendiola RP Jr. Diagnostic peritoneal lavage. Surgery 1965;57:633-7.

9. Tsikitis V, Biffl WL, Majercik S, Harrington DT, Cioffi WG. Selective clinical management of anterior abdominal stab wounds. Am J Surg 2004;188:807-12. CrossRef

10. Radwan MM, Abu-Zidan FM. Focussed Assessment Sonograph Trauma (FAST) and CT scan in blunt abdominal trauma: surgeon's perspective. Afr Health Sci 2006;6:187-90.

11. Udobi KF, Rodriguez A, Chiu WC, Scalea TM. Role of ultrasonography in penetrating abdominal trauma: a prospective clinical study. J Trauma 2001;50:475-9. CrossRef

12. Quinn AC, Sinert R. What is the utility of the Focused Assessment with Sonography in Trauma (FAST) exam in penetrating torso trauma? Injury 2011;42:482-7. CrossRef

13. Sabiston DC, Townsend CM, Beauchamp RD, Evers BM. Sabiston textbook of surgery: the biological basis of modern practicsurgical practice series. 18th ed. USA: Saunders WB; 2008.

14.Zinner M, Ashley SW, editors. Maingot's abdominal operations. 11th ed. New York: McGraw-Hill; 2007.

15. Merlotti GJ, Dillon BC, Lange DA, Robin AP, Barrett JA. 
Peritoneal lavage in penetrating thoraco-abdominal trauma. J Trauma 1988;28:17-23. CrossRef

16. Nagy KK, Roberts RR, Joseph KT, Smith RF, An GC, Bokhari F, et al. Experience with over 2500 diagnostic peritoneal lavages. Injury 2000;31:479-82. CrossRef

17. Schwartz SI, Brunicardi FC, Andersen DK, Billiar TR, Dunn DL, Hunter JG, editors. Schwartz's principles of surgery. 9th ed. New York: McGraw-Hill; 2010.

18. Nagel M, Kopp H, Hagmüller E, Saeger HD. Gunshot and stab injuries of the abdomen. [Article in German] Zentralbl Chir 1992;117:453-9. [Abstract]

19. Ertekin C, Yanar H, Taviloglu K, Güloglu R, Alimoglu O. Unnecessary laparotomy by using physical examination and different diagnostic modalities for penetrating abdominal stab wounds. Emerg Med J 2005;22:790-4. CrossRef

20. Nagy KK, Fildes JJ, Sloan EP, Kim DO, Smith RF, Roberts RR, et al. Aspiration of free blood from the peritoneal cavity does not mandate immediate laparotomy. Am Surg 1995;61:790-5.

21. Drost TF, Rosemurgy AS, Kearney RE, Roberts P. Diagnostic peritoneal lavage. Limited indications due to evolving concepts in trauma care. Am Surg 1991;57:126-8.

22. Sriussadaporn S, Pak-art R, Pattaratiwanon M, Phadungwidthayakorn A, Wongwiwatseree Y, Labchitkusol T. Clinical uses of diagnostic peritoneal lavage in stab wounds of the anterior abdomen: a prospective study. Eur J Surg 2002; 168:490-3. CrossRef
23. Thacker LK, Parks J, Thal ER. Diagnostic peritoneal lavage: is 100,000 RBCs a valid figure for penetrating abdominal trauma? J Trauma 2007;62:853-7. CrossRef

24. Henneman PL, Marx JA, Moore EE, Cantrill SV, Ammons LA. Diagnostic peritoneal lavage: accuracy in predicting necessary laparotomy following blunt and penetrating trauma. J Trauma 1990;30:1345-55. CrossRef

25.Zappa MJ, Harwood-Nuss AL, Wears RL, Fallon WF. Objective determination of the optimal red blood cell count in diagnostic peritoneal lavage done for abdominal stab wounds. J Emerg Med 1992;10:553-8. CrossRef

26. Alyono D, Morrow CE, Perry JF Jr. Reappraisal of diagnostic peritoneal lavage criteria for operation in penetrating and blunt trauma. Surgery 1982;92:751-7.

27. Muckart DJ, McDonald MA. Unreliability of standard quantitative criteria in diagnostic peritoneal lavage performed for suspected penetrating abdominal stab wounds. Am J Surg 1991;162:223-7. CrossRef

28. DeMaria EJ, Dalton JM, Gore DC, Kellum JM, Sugerman HJ. Complementary roles of laparoscopic abdominal exploration and diagnostic peritoneal lavage for evaluating abdominal stab wounds: a prospective study. J Laparoendosc Adv Surg Tech A 2000;10:131-6. CrossRef

29. Sweeney JF, Albrink MH, Bischof E, McAllister EW, Rosemurgy AS. Diagnostic peritoneal lavage: volume of lavage effluent needed for accurate determination of a negative lavage. Injury 1994;25:659-61. CrossRef 